\title{
СИСТЕМА УПРАВЛІННЯ РОЗВИТКОМ ПІДПРИЕМСТВА В УМОВАХ ДИНАМІЧНОЇ КОНКУРЕНЦІї
}

\section{FORMATION OF THE ENTERPRISE DEVELOPMENT MANAGEMENT SYSTEM IN THE CONDITIONS OF DYNAMIC COMPETITION}

\author{
Дячков Дмитро Володимирович \\ доктор економічних наук, доцент, \\ Полтавська державна аграрна академія \\ ORCID: https://orcid.org/0000-0002-2637-0099 \\ Бондар Тетяна Анатоліївна \\ кандидат економічних наук, доцент, \\ ДВНЗ «Київський національний економічний університет \\ імені Вадима Гетьмана» \\ ORCID: https://orcid.org/0000-0001-8038-7070 \\ Дарнєв Марко Костянтинович \\ здобувач вищої освіти, \\ Полтавська державна аграрна академія \\ ORCID: https://orcid.org/0000-0002-2685-3840

\section{Diachkov Dmytro \\ Poltava State Agrarian Academy} \\ Bondar Tetiana \\ Kyiv National Economic University named after Vadym Hetman \\ Darnyev Marko \\ Poltava State Agrarian Academy
}

\footnotetext{
У статті актуалізовано дослідження необхідності безперервного розвитку, що є парадигмою сучасного ефективного та конкурентоздатного підприємства. На основі проведених досліджень запропоновано визначати розвиток підприємства як послідовну зміну сфер діяльності, закономірно викликану як реактивною, так і проактивною реакцією менеджменту на вплив фракторів внутрішнього й зовнішнього середовища, 3 метою досягнення стабільного та ефективного стану всіх елементів суб'єкта господарювання. Узагальнено класифікацію видів та фрорм розвитку, яка дозволяє розглядати його як багатогранну та різнобічну зміну якісного стану суб'єкту господарювання. Зазначені особливості визначили доцільність оптимізації системи управління розвитком підприємства до умов зовнішнього та внутрішнього середовища, які дозволили оптимізувати модель системи управління розвитком підприємства на основі механізму фразового переходу, що включає фактори впливу зовнішнього середовища на розвиток підприємства, суб'єкти та об'єкти управління розвитком, рівні системи управління розвитком, механізм фазового переходу, методи і засоби здійснення змін та результат перехід підприємства в перспективну фразу розвитку.

Ключові слова: зовнішнє середовище, конкуренція, механізму фразового переходу, організаційні зміни, система управління, управління розвитком, фрорми та види розвитку.

В статье актуализированы исследования необходимости непрерывного развития, что является парадигмой современного эффективного и конкурентоспособного предприятия. На основе проведенных исследований, предложено определять развитие предприятия как последовательную смену сорер деятельности, закономерно вызванную как реактивной, так и проактивной реакцией менеджмента на воздействие факторов внутренней и внешней среды, с целью достижения стабильного и эффективного состояния всех элементов предприятия. Обобщение классификации видов и форм развития позволило рассматривать его как многогранное и разностороннее изменение качественного состояния субъекта хозяйствования. Указанные особен-
} 
ности определили целесообразность оптимизации системы управления развитием предприятия к условиям внешней и внутренней среды, которые позволили оптимизировать модель системы управления развитием предприятия на основе механизма фразового перехода, что включает фракторы влияния внешней среды на развитие предприятия, субъекты и объекты управления развитием, уровни системы управления развитием, механизм фазового перехода, методы и средства осуществления изменений и результат - переход предприятия в перспективную фразу развития.

Ключевые слова: внешняя среда, конкуренция, механизм фразового перехода, организационные изменения, система управления, управления развитием, формы и виды развития.

The article updates the study of the need for continuous development, which is the paradigm of a modern efficient and competitive enterprise. On the basis of the conducted researches it is offered to define development of the enterprise as consecutive change of spheres of activity, naturally caused by both reactive and proactive reaction of management to influence of internal and external environment factors for the purpose of achievement of a stable and effective condition of all elements of the business entity. Development, which allows us to consider it as a multifaceted and multifaceted change in the quality of the business entity. Among the classification features that determine the types and forms of development were defined: the degree of predictability, location, scale, rapidity of change, content, degree of stability, nature of change, openness, nature of activity, manageability, length, factor, complexity, the carrier of signs, the rate of change, the degree of coverage of the system. The identified features determined the feasibility of optimizing the management system of enterprise development to the external and internal environment, which allowed to optimize the model of enterprise development management system based on the phase transition mechanism, which includes factors influencing the external environment on enterprise development, subjects and objects of development management, levels of development management system, the mechanism of phase transition, methods and means of implementation of changes and the result - the transition of the enterprise into a promising phase of development. Within the proposed model, the process of development management acquires the character of a set the measures aimed at achieving a common goal, covering all aspects of the enterprise. The use of this tool can increase the efficiency of enterprise development management by ensuring the balance and interconnection of changes in all subsystems and system elements. An important aspect of the proposed model is the concept of organizational change management, which is more applied.

Keywords: competition, development management, external environment, forms and types of development, management system, organizational changes, phase transition mechanism.

Постановка проблеми. Будь-яка динамічно фрункціонуюча соціально-економічна система за своєю природою потребує постійного оновлення та розвитку. Ефективні організації стають такими, насамперед, саме завдяки здатності до розвитку та адаптації до мінливого зовнішнього середовища. Мислення категоріями безперервного розвитку $€$ парадигмою сучасного ефрективного та конкурентоздатного підприємства. Відтак, суб'єкти господарювання різних рівнів, форм власності, організаційно-правових форм зростають та змінюються відповідно до вимог зовнішнього середовища, з врахуванням світових процесів глобалізації, цифровізації, переходу до нової фрорми соціальноекономічної взаємодії - панденоміки, появи нових конкурентних фракторів, що висуває новітню вимогу від вітчизняних підприємств до розвитку нових, більш сучасних фрорм виробництва, технології, збуту, просування, інфрорматизації тощо, що актуалізує питання формування релевантної системи управління їх розвитком. Проте, це неможливо без управління, яке базуватиметься на обґрунтованих управлінських рішеннях і фрункціональних технологіях менеджменту, які б відрізнялися ефрективністю, гнучкістю, а також носили б інноваційний характер.

Аналіз останніх досліджень і публікацій. Різним аспектам дослідження розвитку (від визначення сутності, класифрікації, типізації до орормування методів, важелів, інструментів, механізмів, підсистем та стратегій управління розвитком) соціально-економічних систем різних рівнів та форм присвячені наопрацювання ряду зарубіжних та вітчизняних вчених, зокрема Варламової 3. Н., Єрохіної $€$. А., Карліна Є. П., Коверги С. В., Котляревського Я. В., Крючка С. І., Кушнера М. А., Литвиненко А. О., Павлова В. В., Пащенко О. П., Передерієнко Н. І., Погорєлова Ю.С., Раєвнєвої О. В. та інших.

Виділення невирішених раніше частин загальної проблеми. Водночас, зважаючи на потужний теоретичний та методологічний базис предметної області дослідження управління розвитком, досить фррагментарно знайшли відображення аспекти фрормалізації системи управління розвитком на сучасних підприємствах та характеристики її складових. Актуальність обраної проблеми, необхідність розробки наукових основ і практичних рекомендацій, спрямованих на фрормування системи управління розвитком підприємства визначили ціль дослідження. 
Формулювання цілей статті - формування системи управління розвитком підприємства в умовах динамічної конкуренції.

Виклад основного матеріалу дослідження. Незважаючи на очевидність сутності економічного розвитку підприємства, в теорії й практиці менеджменту можна зустріти різні точки зору на визначення даного поняття і характеристики його особливостей. Тому виникає необхідність проаналізувати поняття «розвиток».

Все різноманіття поглядів на розвиток, представлених головним чином у фрілософрській теорії розвитку, можна звести до чотирьох точок зору [2]:

перша група дослідників пов'язує розвиток 3 цілеспрямованістю змін, які не $є$ необхідною умовою і тим більше атрибутом розвитку [1; 6; 11];

друга група розглядає розвиток як процес адаптації до навколишнього середовища, що також $€$ лише його необхідною, але недостатньою умовою [1; 12];

третя група дослідників підміняє розвиток його джерелом - протиріччями системи [5; 8];

четверта - ототожнює розвиток або 3 однією 3 його властивостей - прогресом або ускладненням систем, або 3 однією 3 його фрорм - еволюцією [9; 10].

Зважаючи на зазначене, в межах проведеного дослідження, запропоновано визначати розвиток підприємства як послідовну зміну сорер діяльності, закономірно викликану як реактивною, так і проактивною реакцією менеджменту на вплив фракторів внутрішнього й зовнішнього середовища, 3 метою досягнення стабільного та ефективного стану всіх елементів суб'єкта господарювання. Зазначене трактування не обмежує розвиток соціально-економічної системи однією 3 його ліній - прогресом або однією 3 його фрорм - еволюцією або революцією і передбачає будь-яку якісну зміна системи. Власне тому, узагальнена в дослідженні класиорікація видів та форм розвитку підприємства (рис. 1), дозволяє розглядати його багатогранний та різнобічний характер.

На рис. 1 наведено класифрікацію видів розвитку підприємства з точки зору ознак, які характеризують досліджуване поняття з різних сторін. Відзначимо, що між наведеними градаціями класифрікаційних ознак розвитку підприємства на практиці можливе існування безлічі інших станів, які відрізняються лише ступенем виразності певних властивостей.

Слід зауважити, що розвиток підприємства - це поява чогось нового, що призводить до вдосконалення або підвищення есрективності діяльності підприємства, формує його конкурентні переваги, адаптує його внутрішній потенціал до умов динаміки зовнішнього середовища. Під потенціалом підприємства в даному випадку слід розглядати сукупність різного виду ресурсів [5]. Водночас, наявність потенціалу підприємства не є гарантією досягнення мети, для цього необхідні здібності управління процесами розвитку, а основними його завданнями повинні стати узгодження цілей підприємства та усунення протиріч. Відтак, необхідними умовами розвитку підприємства $€$ зміни, економічне зростання та вдосконалення. Тобто якщо відбуваються лише зміни, у результаті яких не відбулося зростання, то й удосконалення та розвиток не мали місця. Якщо відбулося економічне зростання без змін - розвиток та вдосконалення також не відбулися [3, с. 42].

Необхідність постійних змін в управлінні і методах ведення бізнесу зумовлена як внутрішніми, так і зовнішніми проблемами. Внутрішні проблеми $є$, як правило, срункціональні і організаційні диспропорції, застарілі стиль і методи управління, архаїчні стереотипи поведінки, недоліки планування, обліку тощо. Перехід до насиченого ринку, загострення конкурентної боротьби, висуває як пріоритетне завдання менеджменту забезпечення конкурентоспроможності підприємства. Конкуренція сьогодні все більше стає боротьбою ідей, а не боротьбою ресурсів. На ринку перемагають організації, що постійно пропонують нові інноваційні рішення. При цьому надзвичайного значення набуває швидкість практичного втілення ідей. Динамізм організації, тобто її здатність до швидкого і масштабного маневру власними ресурсами або до ефективної партнерського взаємодії на ринку, перетворюється на вирішальний фрактор конкурентоспроможності. Зміни стають способом життя. Ефрективне управління організацією перетворюється в домінанту менеджменту.

Зазначені особливості визначають доцільність оптимізації системи управління розвитком до умов зовнішнього та внутрішнього середовища. Відтак, в процесі розвитку підприємство здійснює перехід від однієї фрази (стадії) розвитку до іншої, що визначається як стабільний стан його життєдіяльності, що відрізняється певними ознаками і рівнем. Зміна фрази (або стадії) розвитку визначається фразовий перехід. Під фазовим переходом в розвитку слід розуміти перехід в якісно інший стан функціонування, що відрізняється пев- 


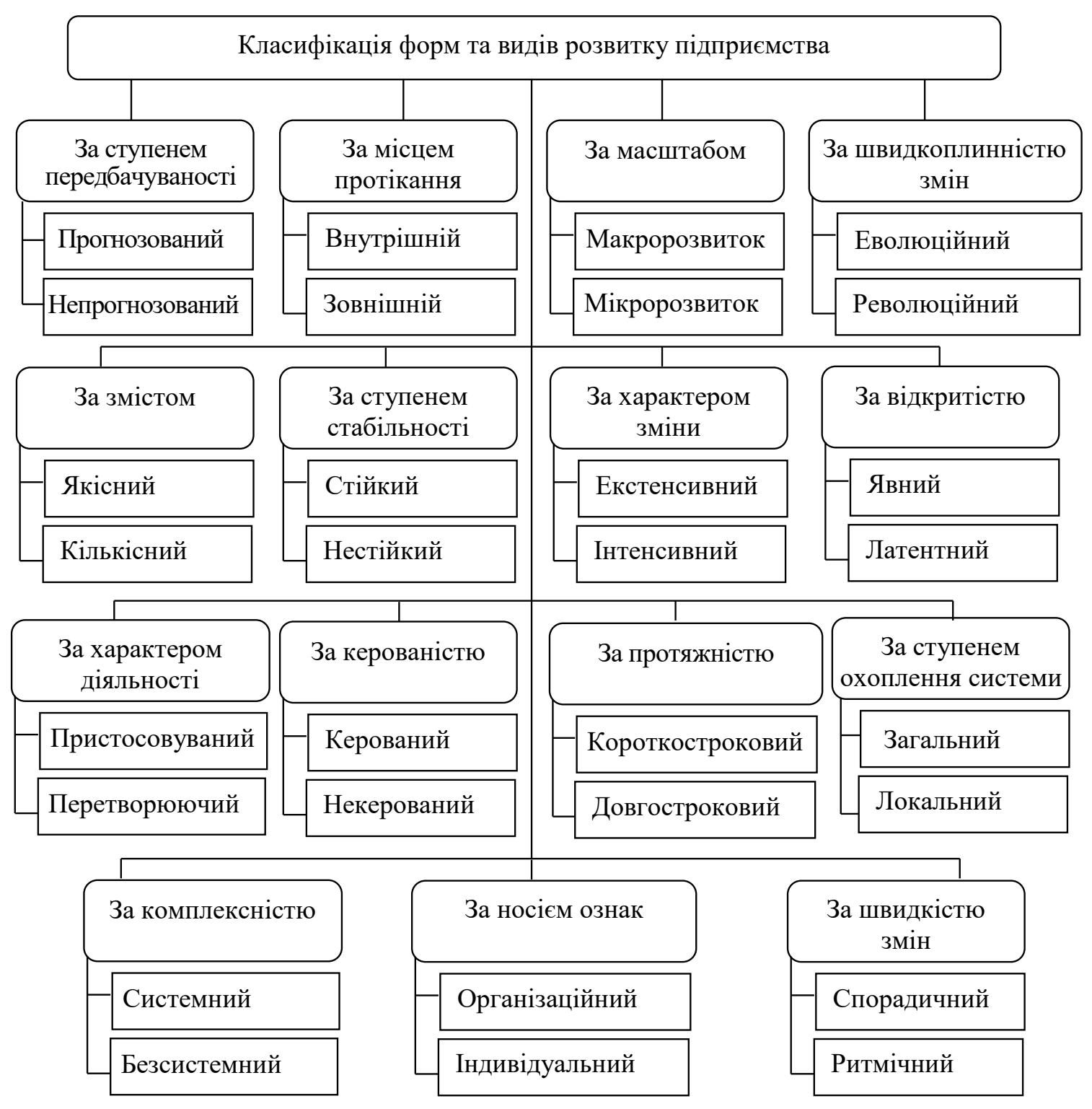

Рис. 1. Класифікація форм та видів розвитку підприємства

Джерело: узагальнено на основі [1; 7]

ними ознаками і рівнем, який здійснюється за допомогою вирішення основоположних протиріч попередньої фрази.

Відтак, система управління розвитком сучасного підприємства на основі механізму сразового переходу представлена на рис. 2. В межах пропонованої моделі, процес управління розвитком набуває характеру комплексу заходів, спрямованих на досягнення єдиної мети, які охоплюють усі сторони життєдіяльності підприємства. В основі моделі системи розвитку підприємства лежать фрундаментальні принципи й закони області знань про розвиток - діалектики.

Особливий інтерес з практичної точки зору представляють закони розвитку, які дозволяють прогнозувати перебіг і результати даного процесу: закон діалектичного синтезу, закон переходу кількості в якість, закон діалектичної суперечливості. Рівнем, в якому принципи і закони розвитку знаходять реалізацію на прикладі організаційної системи, виступає теорія організаційного розвитку. Вона описує типові зміни, що відбуваються в процесі розвитку підприємства.

Розвиток розглядається як процес позитивних якісних змін, основним критерієм розвитку виступає придбання нової якості, що зміцнює життєздатність підприємства. Процес розвитку є поетапним, тому при його здійсненні, підприємство переходить від однієї фрази (або стадії) розвитку до іншої. В якості базової моделі для побудови системи управління розвитком, обрана модель органічного 
Фактори впливу зовнішнього середовищуа на розвиток підприємства

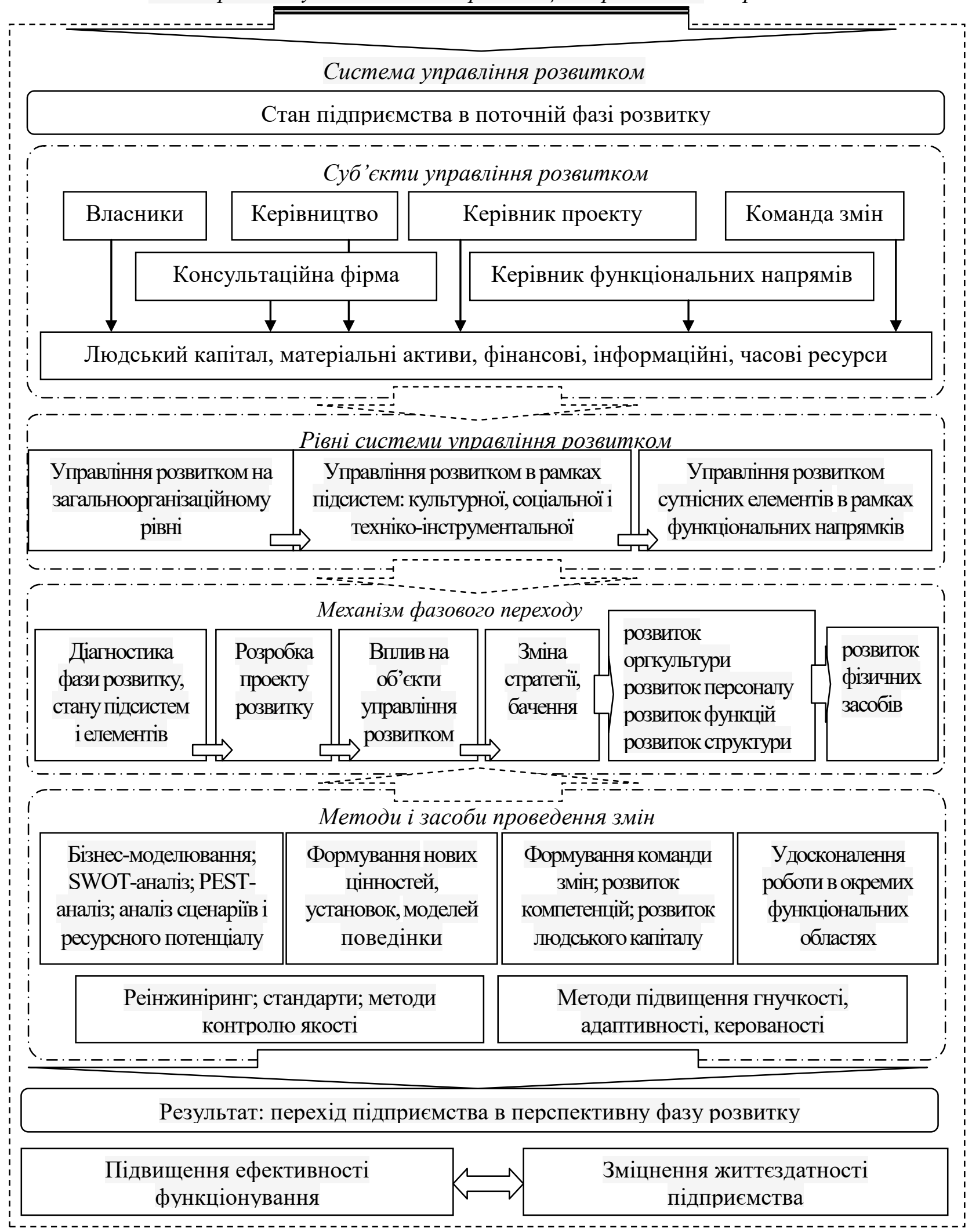

Рис. 2. Модель системи управління розвитком підприємства на основі механізму фразового переходу

Джерело: узагальнено на основі [2; 4; 12; 14] 
еволюційного розвитку підприємства, що включає чотири основні фрази: піонерську, диференціації, інтеграції та асоціації, зміна яких відбувається шляхом подолання відповідних трьох кризових фраз (які виникають як наслідок граничних проблем кожної фрази): кризи піонерської фрази, кризи диференціальної фрази і кризи інтегральної фрази розвитку.

Ще одним важливим складником моделі системи управління розвитком $\epsilon$ функціональні області управління, в яких розглядаються методи і технології розвитку відповідних підсистем і елементів підприємства.

Висновки. Пропонована модель системи управління розвитком підприємства на основі механізму фразового переходу визначає напрямки, послідовність і методи розвиваючих перетворень в основних підсистемах (культурній, соціальній та техніко-інструментальній) для здійснення переходу в наступну фазу розвитку шляхом подолання граничних проблем попередньої фрази. Використання даного інструменту здатне підвищити ефективність управління розвитком підприємства через забезпечення збалансованості та взаємозв'язку змін в усіх підсистемах і елементах системи. Важливим аспектом пропонованої моделі $\epsilon$ концепція управління організаційними змінами, що має в більшій мірі прикладний характер. У центрі пропонованої моделі до управління розвитком підприємства знаходиться модель організації як системи. Системний підхід до організації $€$ сполучною ланкою між концепціями управління розвитком підприємства і іншими областями менеджменту. Його використання дозволяє переходити від загального управління розвитком підприємства до конкретних заходів по функціональних напрямках діяльності товариства. Підприємство в даній моделі виступає як об'єднання трьох підсистем (культурної, соціальної та техніко-інструментальної) й семи складових елементів (ідентичність; політика, стратегія, програми; структура; люди, групи, клімат, керівництво; окремі фрункції, органи; процеси, загальний хід справи; матеріальні ресурси), безперервно взаємодіючих між собою, що утворюють складну динамічну систему, яка розвивається. Таким чином, ссрера управління розвитком розподілена на кілька сфрер, які повністю охоплюють життєдіяльність підприємства.

Визначення фази розвитку здійснюється на основі прояву відповідних критеріїв. Предметом діагностики виступає стан трьох основних підсистем підприємства і складових їх семи сутнісних елементів на різних фразах розвитку. критеріями для діагностики фрази були обрані параметри сутнісних елементів, які вважаються найбільш значущими і вимірними.

\section{СПИСОК ВИКОРИСТАНИХ ДЖЕРЕЛ:}

1. Варламова 3. Н. Сущность развития организаций. Вестник Челябинского государственного универcumema. 2009. № 19. C. 156-160.

2. Ерохина Е. А. Теория экономического развития: системно-синергетический подход. URL: http://ek-lit.agava.ru/eroh/index/html

3. Жилінська Л. О. Управління розвитком машинобудівних підприємств на стратегічну перспективу : дис. ... доктора екон. наук : 08.00 .04 «Економіка та управління підприємствами (за видами економічної діяльності)». Маріуполь, 2016. 436 C.

4. Коваленко Н. В. Система управління розвитком підприємства та ї̈ складники. Проблеми системного підходу в економіці. 2019. Вип. № 4(72). С. 98-107.

5. Коверга С. В. Управління збалансованим розвитком промислових підприємств : авторефр. дис. ... д-ра екон. наук : 08.00.04. Донбас. держ. машинобуд. академія. Краматорськ, 2015. 40 с.

6. Крючок С. І. Управління стійким економічним розвитком сільськогосподарських підприємств : автореф. дис. ... канд. екон. наук : 08.00.04 / Дніпр. держ. аграр.-екон. ун-т. Дніпро, 2018. 20 с.

7. Кушнер М. А., Карлина Е. П. Концептуальные основы управления развитием предприятия. Вестник ЮжноУральского государственного университета. Серия : Экономика и менеджмент. 2011. № 21(238). С. 112-117.

8. Литвиненко А. О. Управління розвитком матеріально-технічної бази підприємства : автореф. дис. ... канд. екон. наук : 08.00 .04 / Харк. нац. екон. ун-т ім. С. Кузнеця. Харків : Харк. нац. екон. ун-т, 2015. 20 с.

9. Павлов В. В. Креативні технології в системі управління розвитком підприємства : авторефр. дис. ... канд. екон. наук : 08.00.04. Київ. нац. ун-т технологій та дизайну. Київ, 2015. 20 с.

10. Пащенко О. П. Стратегічне управління розвитком підприємства. Вісник Хмельницького національного університету. 2011. № 2. Т. 2. С. 99-103.

11. Передерієнко Н. І., Котляревський Я. В. Сутнісно-змістовна характеристика процесів управління розвитком підприємств. Наукові записки Української академії друкарства. 2012. № 2. С. 103-111. 
12. Погорєлов Ю. С. Розвиток підприємства: поняття та види. URL: http://www.nbuv.gov.ua/Articles/Kultnar/ knp88/knp88_75-81.pdf

13. Раєвнєва О. В. Управління розвитком підприємства: методологія, механізми, моделі : монограсрія. ВД «ННЕК», 2006. 496 c.

14. Чемезов И. С. Система управления развитием предприятия на основе механизма фразового перехода : автореферат дис. ... кандидата экономических наук : 08.05.00. Пенза, 2011. 24 с.

\section{REFERENCES:}

1. Varlamova Z. N. (2009) Sushchnost' razvitiya organizatsiy [The essence of the development of organizations]. Vestnik Chelyabinskogo gosudarstvennogo universiteta, no. 19, pp. 156-160. (in Russian)

2. Yerokhina Ye. A. Teoriya ekonomicheskogo razvitiya: sistemno-sinergeticheskiy podkhod [The theory of economic development: a system-synergetic approach]. Available at: http://ek-lit.agava.ru/eroh/index/html (in Russian)

3. Zhylins'ka L. O. (2016) Upravlinnya rozvytkom mashynobudivnykh pidpryyemstv na stratehichnu perspektyvu [Management of development of machine-building enterprises on strategic perspective]: dys. ... doktora. ekon. nauk: 08.00.04 «Ekonomika ta upravlinnya pidpryyemstvamy (za vydamy ekonomichnoyi diyal'nosti)». Mariupol', 436 p. (in Ukrainian)

4. Kovalenko N. V. (2019) Systema upravlinnya rozvytkom pidpryyemstva ta yiyi skladnyky [Enterprise development management system and its components]. Problemy systemnoho pidkhodu $v$ ekonomitsi, no. 4(72), pp. 98-107. (in Ukrainian)

5. Koverha S. V. (2015) Upravlinnya zbalansovanym rozvytkom promyslovykh pidpryyemstv [Management of balanced development of industrial enterprises]: avtoref. dys. ... d-ra ekon. nauk: 08.00.04. Donbas. derzh. mashynobud. akademiya. Kramators'k, 40 p. (in Ukrainian)

6. Kryuchok S. I. (2018) Upravlinnya stiykym ekonomichnym rozvytkom sil's'kohospodars'kykh pidpryyemstv [Management of sustainable economic development of agricultural enterprises]: avtoref. dys. ... kand. ekon. nauk: 08.00.04 / Dnipr. derzh. ahrar.-ekon. un-t. Dnipro, 20 p. (in Ukrainian)

7. Kushner M. A., Karlina Ye. P. (2011) Kontseptual'nyye osnovy upravleniya razvitiyem predpriyatiya [Conceptual foundations of enterprise development management]. Vestnik Yuzhno-Ural'skogo gosudarstvennogo universiteta. Seriya: Ekonomika i menedzhment, no. 21(238), pp. 112-117. (in Russian)

8. Lytvynenko A. O. (2015) Upravlinnya rozvytkom material'no-tekhnichnoyi bazy pidpryyemstva [Management of development of material and technical base of the enterprise]: avtoref. dys. ... kand. ekon. nauk: 08.00.04 / Khark. nats. ekon. un-t im. S. Kuznetsya. Kharkiv: Khark. nats. ekon. un-t, 20 p. (in Ukrainian)

9. Pavlov V. V. (2015) Kreatyvni tekhnolohiyi v systemi upravlinnya rozvytkom pidpryyemstva [Creative technologies in the management system of enterprise development]: avtoref. dys. ... kand. ekon. nauk: 08.00.04. Kyyiv. nats. un-t tekhnolohiy ta dyzaynu. Kyiv, 20 p. (in Ukrainian)

10. Pashchenko O. P. (2011) Stratehichne upravlinnya rozvytkom pidpryyemstva [Strategic management of enterprise development]. Visnyk Khmel'nyts'koho natsional'noho universytetu, no. 2, T. 2, pp. 99-103. (in Ukrainian)

11. Perederiyenko N. I., Kotlyarevs'kyy Ya. V. (2012) Sutnisno-zmistovna kharakterystyka protsesiv upravlinnya rozvytkom pidpryyemstv [Essential and substantive characteristics of business development management processes]. Naukovi zapysky Ukrayins'koyi akademiyi drukarstva, no. 2, pp. 103-111. (in Ukrainian)

12. Pohoryelov Yu. S. Rozvytok pidpryyemstva: ponyattya ta vydy [Enterprise development: concepts and types]. Available at: http://www.nbuv.gov.ua/Articles/Kultnar/knp88/knp88_75-81.pdf (in Ukrainian)

13. Rayevnyeva O. V. (2006) Upravlinnya rozvytkom pidpryyemstva: metodolohiya, mekhanizmy, modeli [Management of enterprise development: methodology, mechanisms, models]: monohrafiya [a monograph]. VD «INZHEK», 496 p. (in Ukrainian)

14. Chemezov I. S. (2011) Sistema upravleniya razvitiyem predpriyatiya na osnove mekhanizma fazovogo perekhoda [System of enterprise development management on the basis of the phase transition mechanism]: avtoreferat dis. ... kandidata ekonomicheskikh nauk: 08.05.00. Penza, 24 p. (in Russian) 